\title{
CZECH HUMAN GEOGRAPHY: RESEARCH AND PROBLEMS
}

I. Bičík, M. Hampl: Czech Human Geography: Research and Problems. Geografie Sborník ČGS, 105, 2, pp. 118 - 128 (2000). The contribution has two main aims. Firstly, it is an evalution of contemporary research trends in the Czech human geography. The consequences of the recent long - lasting isolation of the Czech Republic, as well as the impact of current world human geography are both explored and assessed. Secondly, theoretical issues of human geography are discussed, such as the cognitive function of geography, its relations to social and environmental sciences, problem of regularities in human geographical realm, etc.

KEY WORDS: paradigms of human geography - research topics - classification of real systems - hierarchical organization.

The authors would like to thank Grant Agency of the Czech Republic (project number 403/99/1006/) for support of this contribution.

\section{Introduction}

The aims of this contribution are of two kinds. The first one is, in a number of aspects, of an informative nature, as it is related to the characteristics of the Czech human geography at present, and especially in the second half of the 1990's. It thus presents both a description of the thematic orientation, as well as the cognitive and applicable results of the Czech human geography in the period between the two last IGU congresses. Description of the state is nevertheless also connected with an evaluation of the causes and problems of the current research trends. Moreover, the evaluation of such trends requires a wider context in a form of an overview of changes in the Czech human geography, both from the development and international viewpoints.

The second main aim of this contribution is to discuss some general problems of cognitive functions of human geography which, in number of aspects, points out to possible directions of future research. The stress here is placed on the general level of research. The "national specificity" of research, it is argued here, can be considered as being of secondary importance and, in addition, as something which can be directly read off from the overall orientation of the present research, as well as from the particularities of the present development of the society in the Czech Republic (continued of post-Communist social transformation, integration into European structures, etc.). On the contrary, the conceptual questions about the position of geographical research within the integral knowledge of society, as well as of the understanding of the relation between society and environment, problems of regularity or randomness in formation of geographical organization of the society, or the up to now 
ambiguous specification of the research subject of human geography, represent the fundamental problems which, at the same time, represent the main sources of internal doubts within human geography worldwide. The final part of this paper will therefore briefly discuss these issues.

\section{Paradigm transformations in post-war human geography and the isolation of Czech geography}

The development of geography, and of human geography in particular, since the Second World War can be legitimately characterized as unusually dynamic. This dynamism is evident especially in.comparison with the development in the 19th century, as well as in the first half of the 20th century. The transformation of the concept of environmental determinism to the possibilist one was going on for a long time without taking radical forms. For that reason, controversies over idiographic versus nomothetic character of geography or discussions about the relation human - physical geography were not sharp which was certainly due to the still predominantly descriptive character of geography. Also, for that reason, discussions about the key theoretical questions were inconclusive. The situation changed quite dramatically after the Second World War, whereas three principally different concepts appeared in turns over the latter half of this century (see Cloke et al. 1991, Holt - Jensen 1988). The initial paradigm, which can be characterized as idiographic, represented in principal the heritage of the precedent longterm development of geography (Hartshorne 1959). The stress placed on the unique character of geographical phenomena has necessarily led to the preference of descriptive method. A further consequence of this heritage was a limited interest in applied use of geographical findings or in "problem solving" in general. Geography was maintaining its essentially educational and informative function, that it rather a cultural function than a specific scientific/cognitive one.

The descriptive and unproblematic orientation of geography raised a sharp criticism of younger generations of geographers in the late 1950's and in the 1960's in the United Stated and in the United Kingdom. Under the influence of the then fashionable positivist methodology of science a radical attempt was made to build a "nomothetic" geography with a large exact methodical aparatus. The cost of this major methodological and methodical enrichment of geography was nevertheless a substantial reduction of the qualitative content of geographical systems. Therefore, positivist geography has been often qualified as "spatial science"., It is, however, necessary to mention also other contributions of this period, such as the integration of the formerly isolated school of location theories into the geographical cognitive system, world-wide spread of the research findings of the so-called Lund School (Hägerstrand 1967) or systemization of methods and models (Haggett et al. 1977). The principal expected aims were nevertheless not attained, because the exaggerated interest in space structures lead to their breaking away from the "conditioning forces". Furthermore, the search for regularities in the organization of space per se did not bring any convincing results.

Another decisive upheaval occurred in the 1970's in connection with the interest in spatial manifestations of social differentiation and social problems. 
A considerable wave of humanization followed that resulted in the explicit declaration of human geography as a social science and thus leading to a further deepening of the long-term dichotomy between human and physical geography. This new post-positivist paradigm, however, is not of an integrating type, as, by emulating the example of sociology, it creates space for diversification of research orientations of both structuralist and voluntarist type. The positive contribution of this wave is especially the stress put upon the problem orientation and the attantion paid to human activities. In a simplified manner we can speak about a shift from studying location of phenomena to studying location of problems, and/or from a geography of "passive objects" to a geography of "active subjects". The increased interdisciplinary character of research can be viewed as another enrichment. However, the issue of a controversial existence of geographical regularities and organizational principles is still present here. The explanation of geographical circumstances is primarily seen in the internal organization of the society that is in the circumstances that represent traditional domains of sociology, economics or political science.

The above characteristics thus allow for both positive and negative evaluations. In the former case, the stress on the dynamic intellectual movement, methodological development, problem orientation and deepening of the interdisciplinary cooperation all need to be pointed out. In the latter case, the lack of conceptual clarification of research within human geography needs to be mentioned at least, as well as the lack of continuity in building a coherent cognitive system. Without such a lack of conceptual clarity it is not possible to explain the principal and quite antagonistic transformations of paradigms within a relatively short time span. However, from the viewpoint of the Czech human geography, these transformations were not quite so dramatic. An obvious reason for this was the isolation of the Czech society, and by that also of geography, from the developments in the outside world. Due to this isolation, the development of knowledge was slower in number of aspects, but nevertheless without losing its continuity. The impact of positivism was most clearly manifested in the form of search for regularities in regional differentiation rather than in the attempt to model spatial structures. The impact of post-positivist trends was somewhat limited, not only because of the political isolation connected with tabooization of many social issues, but also because of a deformation of the social sphere itself. Finally, the impact of discussions within the Soviet geography has also been marginal: going from the inconclusive argument between monistic and dualist conceptions of geography (Anuchin 1960) to the inappropriate attempts to identify the conception of sociogeographical region with the conception of the socalled territorial productive complex (Kolosovski 1958).

In a number of ways, an intensive contact with the applied sphere was very important for the Czech geography during the totalitarian period. In the sphere of applied research, the problem orientation of human geography and the ability of interdisciplinary cooperation were progressively increasing. The most important field of activity was territorial/spatial planning that was relatively little affected by the governing ideology. Quite distinct from the regional planning that represented much more of a bureaucratic and political activity, territorial/spatial planning largely maintained its professional character. In addition, due of the absence of professional regional planning, the content of territorial planning was step by step extending towards the functions of integrated spatial planning. This orientation was near to human geographers, just as was the cooperation with urban planners. 


\section{A major current issue: geography of post-Communist societal transformation}

The radical turn over in the social development of the Czech Republic after 1989 was quickly reflected in the orientation of the human geographical research. It was a consequence of two major, mutually augmenting influences. The first one was dismantling of the barriers to international cooperation and the opening of the possibility to chose freely from various research topics. The second one was a sudden rapid increase in the "demand" for geographical analyses of the transformation process that has just been taking off. This was the case with both the applied, as well as the theoretical research. The historical uniqueness of the process of "return" from a totalitarian to a democratic system, and from a centrally planned economy to a market one, has been connected not only with the rise of many principal practical problems in the post-totalitarian countries, but, at the same time, it has also represented an internationally attractive research theme for social sciences. In addition, the systemic character of transformation processes has directly required the application of current trends in social sciences, including human geography, which are characterized by the above mentioned orientation to practical problems and interdisciplinary approach.

The concentration of research interests on geographical aspects of societal transformation has undoubtedly lead to a sensible thematic rapprochement of the Czech and world human geography, and that in spite of the uniqueness of the transformation of post-totalitarian countries. It has been also due to the fact that post-totalitarian transformation has to be evaluated in a larger context; that is, within the framework of the development of post-industrial society, globalization tendencies and the interaction of global and local, etc. It is equally important to look for answers to general questions concerning the nature of geographical organization, the character of geographical regularities, or the link between human geography and other social sciences on the one hand, and with the environmental sciences on the other hand. It is nevertheless legitimate to distinguish the preferred themes and, on the contrary, the neglected ones in the present research of the Czech human geography. However, this differentiation is rather a consequence of research traditions and of limited research capacities on the side of geographical departments at universities than of the character of transformation processes., It is possible at present to trace four broadly defined "preferred" research topics:

(1) The greatest attention has been paid to the problems of regional development, including the issues of territorial administration, development of the settlement system and of the regional policy. Although many papers mainly dealt with partial components of development of regional differentiation (unemployment, banking, foreign investments, etc.), there was also a marked tendency to grasp the development of regional structures within the Czech Republic in an integrated way. A particular attention was also paid to the supranational connections, especially from the viewpoint of European integration processes (see for example Blažek 1997). Two monographs elaborated by teams of authors (Hampl et al. 1996, 1999) can be pointed out as representing the outcomes of integrally conceived research projects.. Another important publication was "Human Development Report, Czech Republic 1996" (Pavlík et al. 1996), elaborated in an interdisciplinary cooperation co-ordinated by the geographical division of the Faculty of 
Science, Charles University. This research also involved investigations of theoretical geographical issues (Hampl 1998) and was linked up with the development of international cooperation (especially within the IGU Commission "Geography and Public Administration"). Many outputs of the research were also applied in practice: projects of administrative territorial organization, conception of regional policy and forthcoming membership in the European Union in this field, territorial plans of metropolitan regions, etc.

(2) A synthetically aimed regional research work, with a stress put upon the microregional level, has been carried out in joint research of geographical departments within two large grants (one of the Ministry of Foreign Affairs and one of the Grant Agency of the Czech Republic). Both projects are aimed at problems of border regions including trans-border cooperation. This research has been co-ordinated by the Ústí nad Labem branch of the Institute of Sociology, Academy of Sciences of the Czech Republic (see also the information about the project "Geogrant of border regions", Jeřábek 1998) and involved cooperation of geography departments of universities in Brno, Olomouc, Ostrava, Plzeň and Prague (see for instance Dokoupil 1996 and Sindler 1999). A research of that type not only deepens the cooperation of national geographical departments, but also strengthens the CentralEuropean cooperation - close links exist with a number of universities, mainly regional ones, in Germany, Poland, Slovakia and Austria. Major attention has also been paid to the issues of revitalization of protected landscape areas (Vaishar, Mikulík 1996), as well as former military districts (Poštolka 1996 and a collection of papers published in a thematic issue of this journal - no. 3, 1998).

(3) In the late 1980's and in the 1990's a large research team was formed with the aim to study long-term patterns in land use. This project is further related to historical-geographical evaluation of the human-nature interaction, to the research on the current transformation of agricultural sector and of rural settlement (see for instance papers by Bičík 1998, Bičík, Götz 1998). The main base for this research is the Department of Social Geography and Regional Development, Charles University, Prague, which cooperates with the universities in Brno, Olomouc, Ostrava, Plzeň and Ústí nad Labem. A unique data base on Land Use (since the year 1845, including more than 10,000 elementary units), is gradually approaching completion and deserves also a special mention, as does the international presentation of the results of this project, which took place mainly within the IGU Study group "Land Use/ Land Cover Change" and the Global Change Programme (directed by the IHDP and IGBP).

(4) Finally, one of the key themes of the Czech human geography have traditionally been population geography and urban geography. There is also a tradition of close cooperation between geographers and demographers, expressed also by integration of the Department of Demography and Geodemography into the Geographical Section of the Faculty of Science, Charles University, Prague. Key themes in this sphere again reflect the present social changes. Major attention has been paid to migration of population, both in the Czech Republic (see Čermák 1996) and at the international level (see for instance Drbohlav 1997 and Cattan, Grasland, Řehák 1996), as well as to the transformation of inner structures of cities, especially of Prague (see Sýkora 1998). Many papers deal with the regional differentiation of demographic processes, health situation of the population, etc. 
The selection of research themes serves only a basic indicative and guiding purpose. Equally the quoted titles represent only a selection of a much more substantial publication activity - see the information about individual geographical research centres in the Czech Republic listed in another part of this issue. This selection of topics can nonetheless be claimed to provide a more or less representative picture which is based on the analysis of the recent publishing activity. In the period $1996-1998,90 \%$ of the nearly 90 papers published by the largest department of human geography in the Czech Republic concerned one of the four above-mentioned problems. This means in the same time that there are many themes that are not sufficiently cover by research. These are mainly issues in the domain of geography of transport, industry and partly also services and leisure. Papers on the regional geography of foreign countries are also rare, which represents a long-lasting deficiency of the Czech geography, largely due to its limited human and financial sources.

The above-mentioned research "debts" in human geography can be in the first place justified by. a very limited number of university geographers, especially human geographers. Although their number, as well as the number of departments, has substantially increased in the 1990's, human geography still remains a very small discipline. Personal capacities of this discipline are undoubtedly insufficient when taking into consideration the needs of both the applied sphere (for that reason, the graduates have no serious problems with finding a job) and of university teaching - in the 1990's, the increase of the number of students was greater than the increase in the number of university teachers. At the same time, the interest of students in geographical disciplines has been higher than the capacity of geography departments for years. The difficult situation of mainly human geography is also illustrated by the fact that there are in the whole of Czech Republic only two independent departments with a distinctly human geographical orientation (in Prague and in Ostrava) and that in most non-specialized departments of geography physical-geographical is the prevalent orientation. In addition, after the abolition of the Institute of Geography at the beginning of the 1990's, geography has practically lost the possibility of doing research within the Academy of Sciences (small teams work now only in the Institute of Geonics in Brno and in the Institute of Sociology in Prague).

\section{Conceptual problems of human geography: concluding remarks}

Although many problems and limitations of the development of the Czech human geography still remain as a heritage of the totalitarian period, it is fully justified to state that in the 1990's there a principal step has been made in the direction of international trends both in the thematic orientation and in the modes of research. In that sense, the principal conceptual problems of the research have more or less "internationalized" and adopted a more general aspect. Their importance is great, as they represent research issues that have not been answered conclusively as yet. Frequent and often principal changes in the paradigm of human geography are an expression of this inconclusiveness because very often they concentrate more on the criticism of the previous concepts than on answering real issues, such as the subject specification of human geography, its position within the system of sciences, the question of existence of geographical regularities, etc. It is 
therefore useful to conclude this paper by addressing several of these key problems.

(i) First, it is necessary to specify the subject of study of human geography, which consequently leads to determination of the position of this discipline in the classification of sciences. At present, the conception of human geography as social science is dominating which corresponds to its orientation at social phenomena and processes. But in what human geography differs from the other social sciences? Undoubtedly in its environmental orientation, because it inquires into environmental/geographical organization of the society. This naturally includes not only the aspect of space, but also especially the interaction between society and natural environment. The problem of monism and dualism of geography is thus primarily a problem of human geography, as in this case it is either possible to distinguish social and environmental conception, or, on the contrary, to stress the intersection, or more precisely integration of both conceptions. The position of human geography in the system of sciences must be thus characterized with the help of two classifying dimensions: on the one hand, according to the traditional viewpoint of the evolutionary complexity and, on the other hand, according to the nontraditional (and up to now lacking) viewpoint of structural complexity expressing polarity of the part and of the whole (element - environment). As shown by the included classification scheme, introduction of the principle of structural complexity has a general validity both for the classifications of real system and of empirical sciences. From that point of view, it is then possible to define human geography as an environmental social science and the subject of its study as environmental organization of society (geosocietal systems), see Fig. 1 .

(ii) The classification of real systems themselves (and consequently also of the empirical sciences) is not sufficient for solving the essence of the problem of human geography's cognitive function. For that reason, it is necessary to attempt to answer the question as to whether the geosocietal system represents a specific and relatively autonomous structure in the organization of reality. This is in principle the problem of existence of regularities in organization of those systems, or, more generally, in the organization of the environmental systems. This could solve the long-standing dispute about the idiographic or nomothetic nature of geography. Geography has always dealt in the first place with the study of differentiations in the territorial distribution of qualitatively different phenomena. This subsequently led to a domination of interest in the "spatial structures" and in differences, or, more specifically, peculiarities, that - viewed from another view-point - represent "irregularities" from the rule of spatial structure. On the contrary, science legitimately puts stress on the search for similarities and regularities. This stress is nevertheless manifested in a simplified way. It is even possible to speak about an ideological habit to search for recurrence only in the similarity of partial phenomena and consequently to delimit taxonomic systems of types of those phenomena. Geographical phenomena - settlements, lakes, mountains, nodal regions, etc. - are however extremely differentiated as far as their size is concerned. This does not necessary exclude either recurrence, or regularity in geographical reality. As already shown by Korčák (1941), the differentiation of phenomena may be of certain type, that is regular, and there can exist a repetition of this differentiation within whole geographical systems. It is not difficult to empirically confirm this affirmation. Within geographical (environmental) systems, there is always a regular 


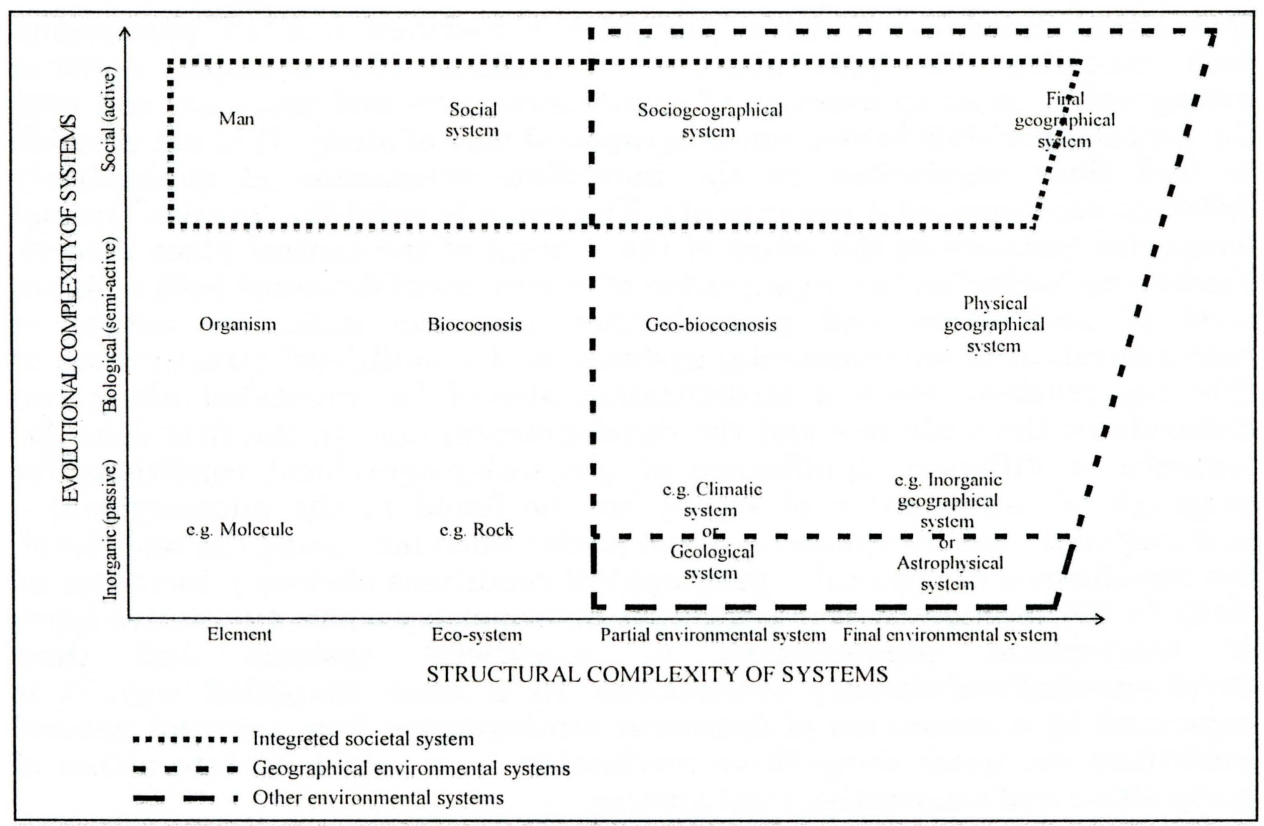

Fig. 1 - Classification of real systems. Source: Hampl et al. 1999, p. 16.

differentiation that can be qualified as a hierarchical one (decreasing frequency of phenomena in relation to an increase in their size). This is valid for settlements as for lakes, being it in the USA, France, Poland, etc. It also means that there exist - within our surrounding reality - two basic types/principles of organization: generic homogeneity of elements and hierarchical differentiation of environmental systems. A logical inference of this is that there are therefore two basic processes of understanding these types of organization: from the whole to its parts and from the parts to the whole. In studying interactions of both types of organization we can identify an integrated understanding of reality. In that sense, the cognitive function of human geography consists of a search for structural and developmental contingencies of hierarchic organizations of geosocietal systems; that is of the highest/most advanced (from the evolutionary point of view) hierarchical organizations of environmental systems. Connection of human geography knowledge with "other" scientific understandings of reality may then be done in two principal directions. The first one is studying interactions of social and natural geographic organizations, that is the development of evolutionarily higher and more advanced geosocietal organization within the physicalgeographical organization. The second one is studying the interaction of the internal (social) organization of the society with its outer (geographical) organization.

(iii) Environmental systems in general, and geosocietal systems in particular, are extremely complex, because their formation results from the interaction of qualitatively different phenomena and processes. In addition, these systems in their total represent a multilevel organized "supersystem", that is, an integral environment. The efforts of geographers to "directly" study geographical environment in its present form could not thus be successful. 
They either ended up as a mere description of distribution of "all" phenomena with stressing the particularities of regions (for example regional monographs), or as an isolation of partial structures and processes and with the consecutive shift to the non-geographical way of study. It is not possible to find clear regularities in the immediate interaction of qualitatively different environmental components. The same is valid for "precise" spatial forms (for instance in the sense of the concept of the central place theory). Finding an "order" in the organization of environment demands both a higher level of abstraction and generalization (see the indicative nature of hierarchization of environmental systems) and a multilevel structuration of this supersystem. Such a structuration should be orientated along two dimensions: the scale one and the developmental one. In the first case, for instance, a different significance of physical-geographical conditions for geographical organization of society can be found at the microregional mezoregional - macroregional - global levels (when increasing the scale level, the significance of physical - geographical conditions obviously increases as well). In the second case it is possible to distinguish various qualitative types of hierarchical organizations of geosocietal systems and their developmental/evolutionary connections. In a more simplified way, it is expressed by a succession of dominant contingencies from external natural conditions via inner competitive mechanism to a combined interaction of competitive and cooperative mechanisms.

\section{Literature:}

ANUČIN, V., A. (1960): Teoretičeskije problemy geografii (Theoretical Problems of Geography). Geografgiz, Moskva, $264 \mathrm{p}$.

BIČÍK, I. (1998): Land use in the Czech Republic 1845 - 1948 - 1990. Methodology, interpretation, contexts. Acta Universitatis Carolinae, Geographia, XXXII, Suppl., pp. 255-263.

BICIK, I., GÖTZ, A. (1998): Czech Republic. In: D. Turnock, ed: Privatization in Rural Eastern Europe. The Process of Restitution and Restructuring. Edw. Elgar Studies of Communism in Transition, Cheltenham, pp. 93-120.

BLAŽEK, J. (1997): The Czech Republic on its way toward the West European structures. European Spatial Research and Policy, 4, No. 1, pp. 37-62.

CATTAN, N., GRASLAND, C., ŘHÁK, S. (1996): Migration flows between the Czech and Slovak Republics: which forms of transformation. In: F. W. Carter, P. Jordan, V. Rey (eds.): Central Europe after the Fall of the Iron Curtain. Peter Lang, Frankfurt am Mein, pp. 319-336.

CLOKE, P., PHILO, CH., SADLER, D. (1991): Approaching Human Geography. An Introduction to Contemporary Theoretical Debates. Chapman Publishing, London, $240 \mathrm{p}$.

ČERMÁK, Z. (1996): Internal migration in the Czech Republic during period of transition. Acta Facultatis Rerum Naturalium Universitatis Comenianae, Geographica, 37, pp. 122-130.

DOKOUPIL, J. (1996): Der Einflu der Grenzöffnung auf die Bewohner im tschechischbayerischen Grenzraum in der Euroregio Egrensis. The influence of the border opening on the inhabitants in the Czech-Bavarian border space in the Euroregio Egrensis. Arbeitsmaterial ARL, 231, ARL, Hannover, pp. 59-68.

DOSTÁL, P. (1998): Democratization, economic liberalization and transformational slump: a cross - sectional analysis of twenty - one postcommunist countries. Environmental and Planning C, Government and Policy, 16, No. 3, pp. 281-306.

DRBOHLAV, D. (1997): Migration policy objectives for European East - West international migration. International Migration, 35, No. 1, pp. 85-108.

HÄGERSTRAND, T. (1967): Innovation Diffusion as a Spatial Process. University of Chicago Press, Chicago, $334 \mathrm{p}$.

HAGGETT, P., CLIFF, A.,D., FREY, A. (1977): Locational Models, Locational Methods. Edward Arnold, London, 605 p. 
HAMPL, M. (1998): Realita, společnost a geografická organizace: hledání integrálního řádu (Reality, Society and Geographical Organization: Searching for an Integral Order). Př́rodovědecká fakulta Univerzity Karlovy, Praha, 110 p.

HAMPL, M. et al. (1996): Geografická organizace společnosti a transformační procesy $\mathrm{v}$ České republice (Geographical Organization of Society and Transformational Processes in the Czech Republic). Fakulty of Science, Charles University, Prague, 395 p.

HAMPL, M. et al. (1999): Geography of Societal Transformation in the Czech Republic. Fakulty of Science, Charles University, Prague, 242 p.

HARTSHORNE, R. (1959): Perspective on the Nature of Geography. Rand McNally, Chicago.

HOLT - JENSEN, A. (1988): Geography. History and Concepts. Paul Chapman Publiching Ltd, 2nd ed., London, 186 p.

JEŘABEK, M. (1998): Geogrant pohraničí - společný výzkum geografických pracovišt (Geogrant borderland - common research of geographical institutions). Geografie Sborník české geografické společnosti. 103, No. 4, pp. 458-460.

Katedra sociální geografie a regionálního rozvoje (Department of Social Geography and Regional Development), Fakulty of Science, Charles University, Prague, 83 p.

KOLOSOVSKIJ, N., N. (1958): Osnovy ekonomičeskogo rajonivovanija (Foundation of Economic Regionalization). Gospolizdat, Moskva, 198 p.

KORČÁK, J. (1941): Přírodní dualita statistického rozložení (Natural duality of statistical distribution). Statistický obzor, 22, pp. 171-222.

MIRVALD, S. (1999): Integration des Tschechischen Strassennetzes im Process der Globalisation. In: Globalisation, Regionalisation, Regionalismus. Janus Pannonius Universtät, Pécs, pp. 201-205.

POŠTOLKA, V. (1996): The Environmentally Damaged Areas in the Czech Republic and New Approach to their Assessment and Delimitation. In: Environmental Engineering and Pollution Prevention. European Network of Excellence and Parthnership. NATO ASI Series. Kluwer Dordrecht, pp. 63-80.

PAVLÍK, Z. et al. (1996): Human Development Report. Czech Republic 1996. UNDP, Faculty of Science, Charles University, Prague, $91 \mathrm{p}$.

SÝKORA, L. (1998): Commercial property development in Budapest, Prague and Warsaw. In: G. Enyedi ed.: Social Change and Urban Restructuring in Central Europe. Akadémiai Kiadó, Budapest, pp. 109-136.

ŠINDLER, P. (1999): Political, social, and economical development of Ostrava region in the Czech Republic. Geographical Bulletin, No. 71, Association of the Geographical Societies of Slovenia, Ljubljana, pp. 121-128.

VAISHAR, A., MIKULÍK, O. (1996): Economic Revitalization in Protected Landscape Areas. In: Transformation Processes of Regional Systems in Slovak Republic and Czech Republic. Univerzita Komenského Bratislava, pp. 148-154.

\section{Shrnutí}

\section{ČESKÁ HUMÁNNÍ GEOGRAFIE: TÉMATA A PROBLÉMY VÝZKUMU}

Příspěvek je zaměřen na dva druhy problematik. Prvou je hodnocení změn ve výzkumné orientaci české sociální, resp. humánní geografie v průběhu 90. let. Je konstatováno rychlé přibližování k světovým trendům, které pochopitelně odpovídá společenským změnám po roce 1989, a tedy překonání někdejší politické, a proto i společenskovědní izolaci české společnosti. Transformační období přináší navíc významné aktuální problémy ve sféře regionálního vývoje, územní administrativy, sociální ekologie apod. Transformace post - totalitních zemí se tak stává „velkým tématem“ i pro sociální geografii. Atraktivita této problematiky není přitom omezena jen na sféru aplikovaného výzkumu, ale uplatňuje se i ve sféře výzkumu základního. V druhém případě nabývá na důležitosti i v kontextu mezinárodního výzkumu díky unikátní povaze procesu „návratu k demokracii a k tržní ekonomice“.

Současná česká sociální geografie, právě v důsledku svého otevření vůči světu, pocituje ovšem i zesíleným způsobem neuzavřenost diskusí klíčových teoretických otázek studia. $\mathrm{K}$ těm patří stále se vynořující problém její předmětové specifikace vyjádřený dualitou možného přiřazení bud' $\mathrm{k}$ sociálním nebo naopak $\mathrm{k}$ environmentálním vědám: připojené klasifikační schéma vyjadřuje $\mathrm{v}$ tomto smyslu pozici předmětu sociální geografie v průniku obou zmíněných skupin věd, resp. odpovídajících reálných systémů. Ještě závažnější je otázka 
existence geografických, resp. geosocietálních pravidelností/zákonitostí. V tomto případě je možno rovněž zdůrazňovat „neobvyklost“ geosocietální reality, resp. environmentálních systémů obecně: základním typem pravidelností jsou hierarchicky uspořádané velikostní diferenciace jevů v rámci environmentálních systémů.

Obr. 1 - Klasifikace reálných systémů. Vyznačená ohraničení se týkají integrovaného společenského systému (zahrnuje člověka, sociální systém i sociogeografický systém); geografických a ostatních environmentálních systémů. Sociogeografické systémy jsou tedy určeny průnikem sociálních a environmentálních reálných systémů (podrobněji viz Hampl a kol. 1999).

(Authors are with Department of Social Geography and regional Development, Faculty of Science, Charles University, Albertov 6, 12843 Praha 2, Czech Republic.)

Arrived to the editor's office on January 15, 2000 